\title{
ARTICLE
}

\section{Flavored little cigar smoke induces cytotoxicity and apoptosis in airway epithelia}

\author{
Arunava Ghosh ${ }^{1}$, Rachel C Nethery ${ }^{2}$, Amy H Herring ${ }^{2}$ and Robert Tarran ${ }^{1,3}$
}

Addition of flavors reduces the harsh taste of tobacco, facilitating the initiation and maintenance of addiction among youths. Flavored cigarettes (except menthol) are now banned. However, the legislation on little cigars remains unclear and flavored little cigars are currently available for purchase. Since inhaled tobacco smoke directly exerts toxic effects on the lungs, we tested whether non-flavored and flavored little cigar smoke exposure had the potential for harm in cultured pulmonary epithelia. We cultured Calu-3 lung epithelia on both 96-well plates and at the air-liquid interface and exposed them to smoke from non-flavored Swisher Sweets and flavored (sweet cherry, grape, menthol, peach and strawberry) Swisher Sweets little cigars. Irrespective of flavor, acute little cigar smoke exposure $(10 \times 35 \mathrm{ml}$ puffs) significantly increased cell death and decreased the percentage of live cells. Chronic exposure $(10 \times 35 \mathrm{ml}$ puffs per day for 4 days) of smoke to Calu- 3 cultures significantly increased lactate dehydrogenase release, further indicating toxicity. To determine whether this exposure was associated with increased cell death/apoptosis, a protein array was used. Chronic exposure to smoke from all types of little cigars induced the activation of the two major apoptosis pathways, namely the intrinsic (mitochondrial-mediated) and the extrinsic (death receptor-mediated) pathways. Both flavored and non-flavored little cigar smoke caused similar levels of toxicity and activation of apoptosis, suggesting that flavored and nonflavored little cigars are equally harmful. Hence, the manufacture, advertisement, sale and use of both non-flavored and flavored little cigars should be strictly controlled.

Cell Death Discovery (2017) 3, 17019; doi:10.1038/cddiscovery.2017.19; published online 24 April 2017

\section{INTRODUCTION}

Tobacco smoking and second-hand smoke exposure are major causes of mortality and morbidity worldwide. ${ }^{1}$ According to the National Adult Tobacco Survey (2013-2014), cigars, cigarillos and filtered little cigars constitute the second largest group of consumed combustible tobacco products. ${ }^{2}$ Little cigars are combustible tobacco weighing $<3 \mathrm{lbs}$ per 1000 units and are filler wrapped in tobacco leaf or tobacco-containing material. Little cigars have also been perceived as 'safer' than cigarettes, although no data exist regarding this., ${ }^{3,4}$ Each day, more than 3800 youths $<18$ years of age smoke their first cigarette and flavored tobacco products may facilitate smoking. ${ }^{5}$ Flavored tobacco products are especially appealing to younger smokers as they may mask the harsh taste of tobacco, resulting in the initiation, amplification and continued addiction to tobacco products. ${ }^{6}$ Enticing flavors like fruit, menthol, liquor, candy and coffee, along with attractive packaging, help in new tobacco user recruitment. ${ }^{6}$ In the United States of America, with the issuing/implementation by the Food and Drug Administration (FDA) of a finalized rule in May 2016, all tobacco products are subjected to the Federal Food, Drug and Cosmetic Act (the FD\&C Act), as amended by the Family Smoking Prevention and Tobacco Control Act (Tobacco Control Act). Hence, little cigar distribution and sales are now controlled, with warning statements being required on packaging. Although only menthol flavoring is allowed in cigarettes, diverse flavors are currently permitted in little cigars. However, the FDA accepts the influence of flavors on initiation and continued use of tobacco products and intends to issue a product standard to eliminate flavors from little cigars (Federal Register/Vol. 81, No. 90/Tuesday, 10 May 2016/ Rules and Regulations, pages 28977 and 29024).

Cells typically undergo a complex signaling cascade before undergoing apoptosis/cell death, including release of cytosolic $\mathrm{Ca}^{2+}$ and post-translational modification of several proteins, for example, the cleavage of caspase- 3 , suggesting that proteins in the apoptosis pathway may constitute biomarkers of harm that can be evaluated after tobacco smoke exposure. ${ }^{7,8}$ Furthermore, we have previously demonstrated that cigarette smoke exposure elicits a chronic elevation in intracellular $\mathrm{Ca}^{2+}$ levels. ${ }^{9}$ Cytosolic $\mathrm{Ca}^{2+}$ serves as a universal second messenger that not only control apoptosis but also influences cell division/growth and gene expression. ${ }^{10,11}$ Furthermore, abnormal $\mathrm{Ca}^{2+}$ homeostasis has been linked to several pathologies including lung, prostate, breast, skin and colon cancers. ${ }^{12}$ We and others have previously shown that Calu-3 pulmonary epithelial cells show similar, $\mathrm{Ca}^{2+}$-dependent inhibition of the cystic fibrosis transmembrane conductance regulator (CFTR) as seen in humans, suggesting that they are a good model for tobacco exposure. ${ }^{13,14}$ Since this inhibition of CFTR was $\mathrm{Ca}^{2+}$-dependent, ${ }^{9}$ we therefore tested the ability of flavored and non-flavored little cigars to induce apoptosis/cell death in vitro using the Calu-3 cell line.

Although several studies have investigated the effects of individual flavors on biological systems, ${ }^{15-20}$ the effect of flavored tobacco smoke on human airway epithelia has not been determined. Our present study was designed to evaluate the relative toxicity induced by flavors by exposing cultured airway epithelial cells to regular versus flavored little cigar smoke. We also

\footnotetext{
${ }^{1}$ Marsico Lung Institute, University of North Carolina at Chapel Hill, Marsico Hall, 125 Mason Farm Road, Chapel Hill, NC, USA; ${ }^{2}$ Department of Biostatistics, Chapel Hill, NC, USA and ${ }^{3}$ Department of Cell Biology and Physiology, University of North Carolina, Chapel Hill, NC, USA.

Correspondence: R Tarran (robert_tarran@med.unc.edu)

Received 20 December 2016; revised 7 February 2017; accepted 23 February 2017; Edited by AE Sayan
} 
evaluated the autophagic response of epithelial cells to nonflavored and flavored little cigar smoke exposure. Furthermore, changes in different apoptotic proteins after chronic exposure of non-flavored and flavored little cigar smoke were evaluated using an apoptosis protein array system.

\section{RESULTS}

Acute flavored little cigar smoke exposure causes increased apoptosis and cell death

To evaluate the relative effects of non-flavored versus flavored little cigars, we exposed Calu-3 cells cultured on 96-well plates to little cigar smoke with air exposure serving as the control. Acute exposure to little cigar smoke (that is, 10 puffs) significantly decreased the percentage of live cells and significantly increased the percentage of dead cells, irrespective of flavoring (Figures 1a and $b$ ). Although there was no significant difference between most flavors and the non-flavored brand, peach flavor caused a significantly greater decrease in the percentage of live cells compared with non-flavored smoke. Four out of five flavors tested (grape, menthol, peach and strawberry) also significantly increased cell death compared with the non-flavored little cigar group (Figures 1a and b).

Relocation of phosphatidylserine from the inner side of the plasma membrane to the cell surface is an early event of apoptosis that can be detected by the binding of Annexin- $V$ to phosphatidylserine to identify proapoptotic cells. ${ }^{21}$ Additionally, DAPI can be used as a viability exclusion dye in unpermeabilized cells. ${ }^{22}$ To further support our cytotoxicity observations, we stained live unpermeabilized Calu-3 cells cultured on 96-well plates with Annexin-V and DAPI to detect proapoptotic and inviable cells, respectively. The proapoptotic and inviable cells were significantly increased in non-flavored and flavored little cigar smoke-exposed cells compared with the air exposure as indicated by increased Annexin-V and DAPI binding (Figures $2 a$ and b). Four out of five flavors (sweet cherry, grape, menthol and peach) significantly increased Annexin- $V$ fluorescence indicating increased numbers of proapoptotic cells compared with non-flavored little cigar smoke (Figure 2a). No significant difference in DAPI uptake was observed between non-flavored and flavored little cigar smoke groups (Figure 2b).

Acute exposure to both non-flavored and flavored little cigar smoke significantly increased autophagosome formation in Calu-3 cells as detected with an Autophagy Assay Kit (Sigma-Aldrich, MO, USA) (Figure 2c). However, for two out of five flavors (that is, grape and menthol) while the increase was less than for non-flavored tobacco exposure, it was still significantly greater than the air control (Figure 2c). These observations indicate that despite the inclusion of flavors to mask any harsh taste, cytotoxicity remains unaltered.

Acute flavored little cigar exposure increases cytosolic $\mathrm{Ca}^{2+}$ levels Intracellular calcium acts as an important second messenger that regulates cellular signaling including changes in gene expression and the transition to apoptosis. ${ }^{23}$ Cigarette smoke exposure has previously been shown to elicit an increase in intracellular $\mathrm{Ca}^{2+9}$ Hence, we measured changes in intracellular $\mathrm{Ca}^{2+}$ levels by staining live cells with the calcium-sensitive dye Fluo-4 and monitoring fluorescence before and immediately after 10 puffs of exposure to non-flavored and flavored little cigar smoke. Significant increases in intracellular $\mathrm{Ca}^{2+}$ concentrations were observed for all of the smoke exposure groups, irrespective of flavors (Figure 3). However, no significant difference was observed between non-flavored and flavored little cigar smoke exposure (Figure 3). As a positive control, we further added the SERCA pump inhibitor thapsigargin to deplete the endoplasmic reticulum of $\mathrm{Ca}^{2}$ ${ }^{+}$and increase cytosolic $\mathrm{Ca}^{2+}$ levels. ${ }^{24}$ These data indicated that little cigar exposure increased cytosolic $\mathrm{Ca}^{2+}$ to $\sim 80 \%$ of the thapsigargin-induced response (Figure 3 ).

Chronic flavored little cigar smoke exposure induces cytotoxicity and increased LC3B-II expression

For chronic exposure studies, Calu-3 cells were seeded on semipermeable $12 \mathrm{~mm}$ transwell inserts and cultured at the airliquid interface until they were polarized. Cultures were then exposed to $10 \times 35 \mathrm{ml}$ puffs of whole tobacco smoke every day and cytotoxicity was evaluated by measuring lactate dehydrogenase $(\mathrm{LDH})$ release into the basolateral media following the fourth day of exposure. Compared with air-exposed cultures, little cigar smoke exposure, irrespective of flavors, significantly increased LDH release into the basolateral media (Figure 4a). The degree of $\mathrm{LDH}$ release was unrelated to flavor and was significantly increased in all the smoke exposure groups (Figure 4a).

Autophagy is associated with programmed cell death and has been implicated in disease pathogenesis. ${ }^{25}$ For example, the lungs of COPD patients display increased autophagy. ${ }^{26}$ Microtubuleassociated protein light chain 3 (LC3-II/LC3-I) and autophagyrelated proteins (Atg4, Atg5-atg12 and Atg7) are increased during autophagosome formation and can serve as biomarkers of exposure. ${ }^{26}$ Increased levels of LC3B-II protein in the lungs of
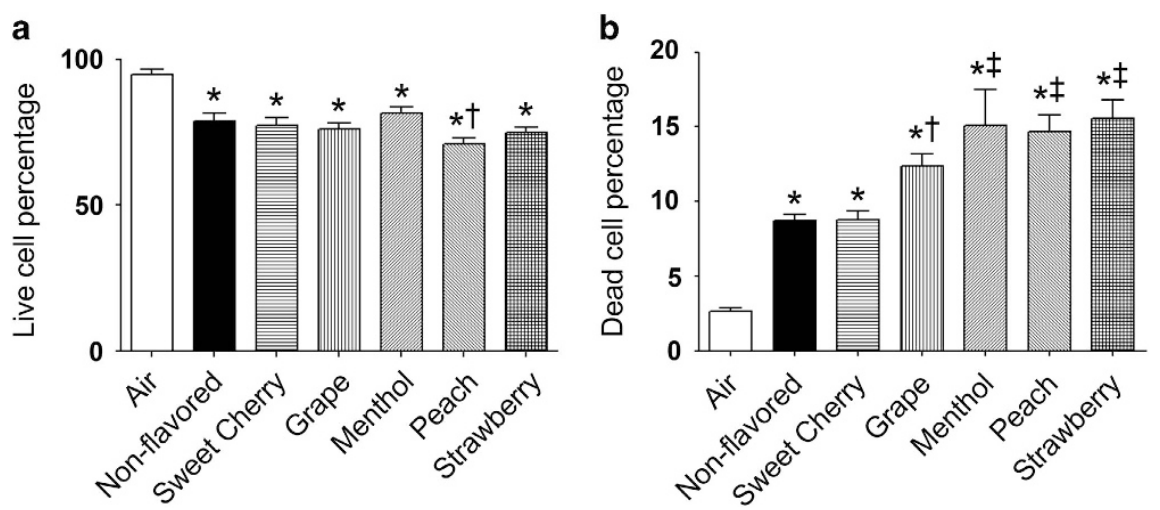

Figure 1. Acute little cigar smoke exposure causes Calu-3 cell death. Calu-3 cells were cultured on 96-well plates and were exposed to $10 \times 35 \mathrm{ml}$ puffs of gas phase smoke from little cigars with or without flavor or air (control). (a) Cells were stained with calcein-AM to identify live cells and (b) stained with and propidium iodide to identify dead cells; $n=70$ wells per bar. ${ }^{*} P \leqslant 0.0001$ compared with air. ${ }^{\dagger} P \leqslant 0.05$ and ${ }^{\ddagger} P \leqslant 0.001$ compared with non-flavored little cigars. Bar graphs represent means \pm S.E.M. 


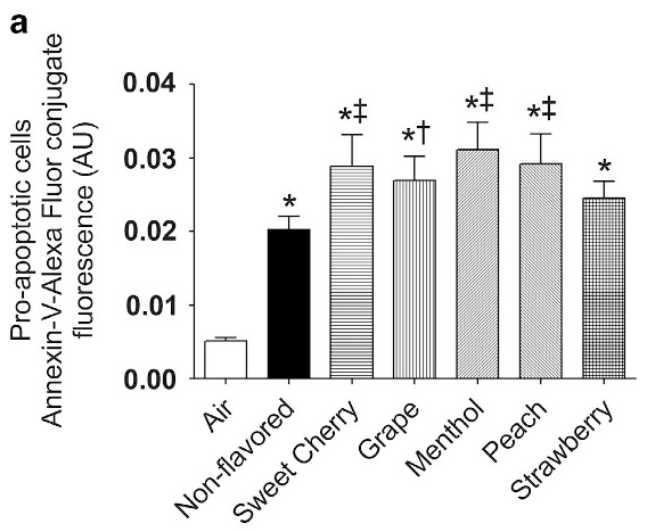

b

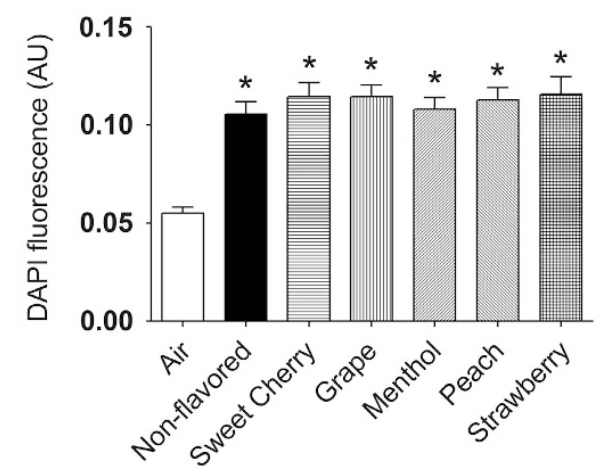

C

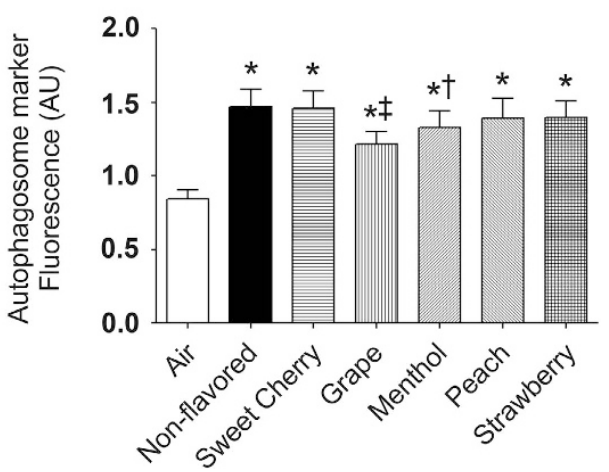

Figure 2. Acute little cigar smoke exposure induces apoptosis and autophagosome formation. Calu-3 cells cultured on 96-well plates were exposed to $10 \times 35 \mathrm{ml}$ puffs of gas phase smoke from little cigars with or without flavor. (a) Live Calu-3 cells were stained with Alexa Fluor 647 conjugate to identify proapoptotic cells. (b) Cells were stained with DAPI to identify inviable cells. (c) Autophagosome formation was identified with a fluorescent autophagosome marker (all $n=50$ wells per bar). ${ }^{*} P \leqslant 0.0001$ compared with air. ${ }^{\dagger} P \leqslant 0.05$ and ${ }^{\ddagger} P \leqslant 0.001$ compared with non-flavored little cigars. Bar graphs represent means \pm S.E.M.

COPD patients have previously been identified. ${ }^{27}$ Furthermore, in vitro tobacco smoke exposure has been shown to alter autophagosome formation and affect the expression of related proteins. ${ }^{27}$ We therefore evaluated the induction of autophagy following chronic exposure to flavored little cigar smoke. We chronically exposed polarized Calu-3 cultures to 10 puffs of whole tobacco smoke per day for four days and measured LC3B-II protein levels. LC3B-II was significantly elevated in all of the chronic smoke-exposed groups irrespective of flavor used (Figures $4 \mathrm{~b}$ and $\mathrm{c}$ ). However, no significant difference was observed between flavored and non-flavored little cigar smoke exposures (Figures $4 \mathrm{~b}$ and $\mathrm{c}$ ).

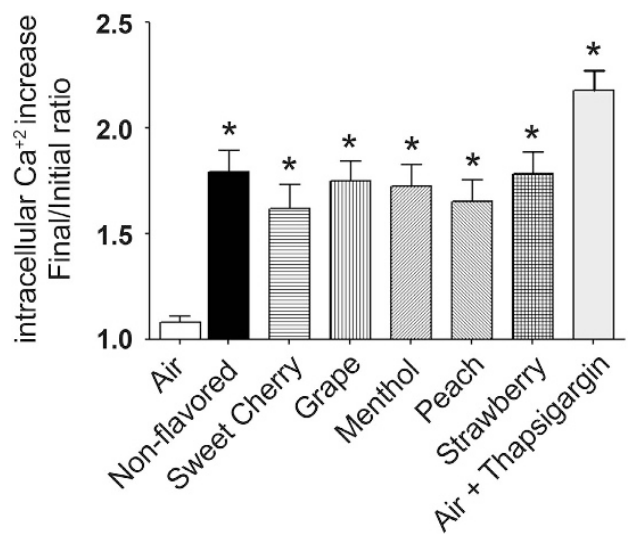

Figure 3. Acute little cigar exposure increases cytosolic calcium levels. Calu-3 cells cultured on 96 -well plates were stained with Fluo4 and fluorescence measurements were recorded both before and after exposure to $10 \times 35 \mathrm{ml}$ puffs of gas phase smoke from little cigars with or without flavor. Intracellular calcium increases were calculated as a ratio of final to initial fluorescence after background subtraction. As a positive control, thapsigargin was added to airexposed wells (all $n=42$ wells per bar). ${ }^{*} P \leqslant 0.0001$ compared with air. Bar graph represents means \pm S.E.M.

Chronic flavored little cigar smoke exposure alters key apoptotic proteins

Apoptotic cell death plays a crucial role in pulmonary disease progression. ${ }^{28,29}$ Apoptosis is driven by both the intrinsic and extrinsic pathways. "While the extrinsic pathway depends on plasma membrane 'death receptors', including members of the tumor necrosis factor (TNF) receptor gene superfamily and activation of subsequent signaling cascades, the intrinsic pathway is regulated by mitochondria and relies on the release of specific proteins like cytochrome $c$, high-temperature requirement ( $\mathrm{HtrA})$ family serine protease 2 (HTRA2/Omi) and second mitochondriaderived activator of caspases/direct inhibitor of apoptosis binding protein with low $\mathrm{pl}$ (Smac/Diablo), which relocate from the mitochondrial intermembrane space into the cytosol to facilitate 'apoptosome' formation.? Whether mitochondria release cytochrome $c$ is determined by the dimerization of pro- and antiapoptotic members of the $\mathrm{BCl}-2$ protein family. ${ }^{7}$ The completion of apoptotic cell death is then performed by a group of cysteine proteases known as 'caspases', especially caspase-3, which following activation by proteolytic cleavage, degrade diverse groups of proteins to achieve this goal. ${ }^{7,30}$ Other proteins that have critical roles in the activation of apoptosis are $\mathrm{p} 53^{31}$ and heat-shock proteins (HSPs). ${ }^{32}$ Additionally, 'inhibitors of apoptosis' proteins (IAPs) are important regulators of cell death. ${ }^{33}$ As many proteins are involved in apoptosis, we compared the levels of several pro- and antiapoptotic proteins in the whole-cell lysates of chronically smoke-exposed Calu- 3 cultures. Out of the 35 proteins tested, we identified the presence of 30 proteins (Figure 5a). Eighteen proteins were altered in chronic smoke-exposed cells. That is, 2 proteins were downregulated and 16 proteins were upregulated after little cigar smoke exposure compared with air (Figure 5a and Table 1). Chronic smoke exposure caused a decrease in the antiapoptotic protein $\mathrm{Bcl}-2$ irrespective of the little cigar flavor (Figure $5 \mathrm{a}$ and Table 1). Coupled to this, the proapoptotic mitochondrial protein Bad, which is responsible for mitochondrial membrane pore formation and cytochrome $c$ release, was elevated across all groups (Figure 5a and Table 1), indicating that the intrinsic pathway of apoptosis was activated following chronic smoke exposure. Release of cytochrome $c$ from mitochondrial membranes into the cytosol leads to the activation of caspases, enabling the execution of apoptosis. ${ }^{34}$ Chronic 
a

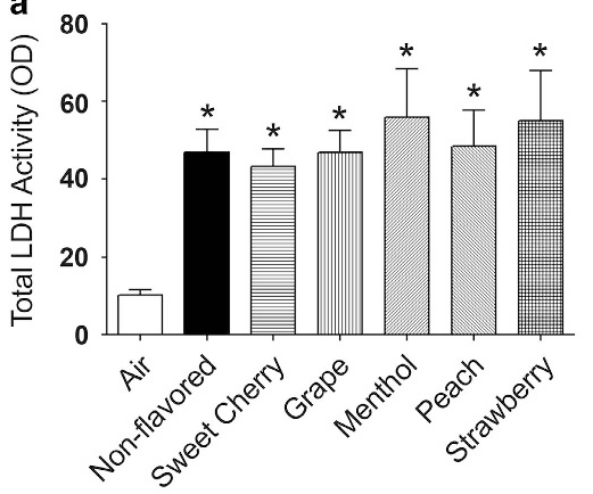

b

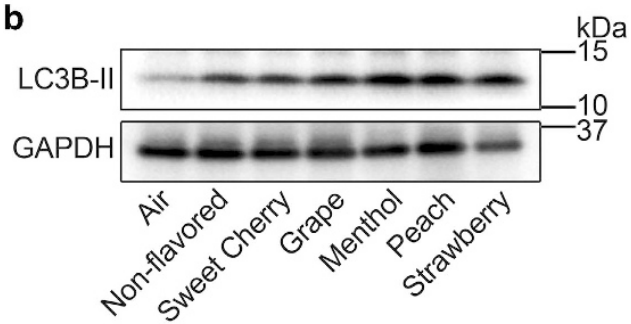

C

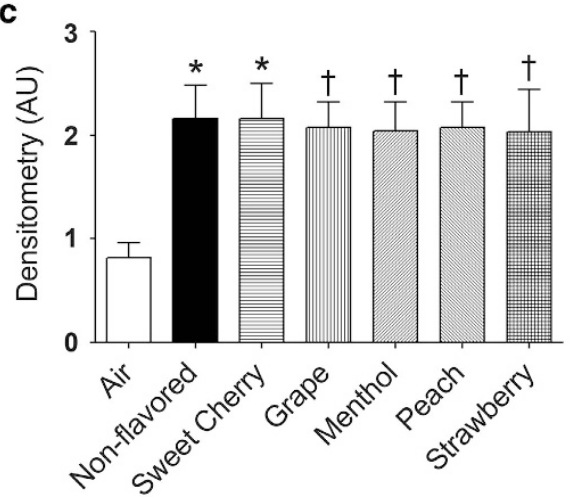

Figure 4. Chronic little cigar smoke exposure induces toxicity and activates autophagy in polarized Calu-3 cultures. Calu-3 cells cultured on transwell-clear inserts were exposed to $10 \times 35 \mathrm{ml}$ puffs per day for 4 days and analyzed for cytotoxicity and autophagic LC3B-II protein expression. (a) On the fourth day, LDH release in the basolateral media was increased following chronic tobacco smoke exposure (all $n=12$ cultures per bar). (b) Representative western blot of autophagic LC3B-II protein with glyceraldehyde 3-phosphate dehydrogenase (GAPDH) as the loading control. (c) Fold change in densitometry ( $n=6$ per bar) of LC3B-II protein levels normalized to GAPDH levels after chronic little cigar smoke exposure, with or without flavors. ${ }^{*} P \leqslant 0.0001$ and ${ }^{\dagger} P \leqslant 0.05$ compared with air. Bar graphs represent means \pm S.E.M.

flavored and non-flavored little cigar smoke exposure increased cytochrome $c$ levels compared with air exposure, further demonstrating the activation of apoptosis for all flavors. In contrast, two mitochondrial proteins, namely HTRA2/Omi and Smac/Diablo, remained unaltered.

'Death receptors' on the plasma membrane bind to their respective ligands, triggering cell signaling cascades, ${ }^{7}$ leading to caspase activation and activation of the extrinsic pathway of apoptosis. In chronically smoke-exposed cultures, TRAIL R1/DR4, TRAIL R1/DR5 as well as TNF RI/TNFRSF1A receptors were significantly increased (Figure $5 \mathrm{a}$ and Table 1) in both flavored and non-flavored smoke exposure groups, indicating that little cigar smoke exposure induced the formation of death receptors irrespective of flavors. However, the protein levels of tumor necrosis factor receptor superfamily member 6 (Fas/TNFRSF6/ CD95) receptor and Fas-associated protein with death domain (FADD) remained unaltered across the groups (Figure $5 a$ and Table 1).

Stabilization of p53 by phosphorylation (P-p53) has a pivotal role in the progression towards apoptosis in the event of stresses such as DNA damage. ${ }^{35}$ When whole-cell lysates from chronically smoke-exposed cultures were probed with phosphoserine antibodies against the three phosphorylation sites of p53 (Ser-15, -46 and -392), flavored and non-flavored smoke exposure was found to enhance the phopshorylation of all the three sites, with the effects on Ser-46 being the most profound (Figure 5a and Table 1). Three out of five flavors (grape, menthol and peach) significantly increased S46 phosphorylation compared with non-flavored smoke, with grape flavor showing increased S392 phosphorylation compared with non-flavored smoke (Table 1). Our observations indicate that stress caused by chronic exposure of smoke resulted in stabilization of $\mathrm{p} 53$, which subsequently may regulate cell growth and alter transcriptional activation of stress-related genes. Chronic exposure to little cigar smoke regardless of flavor increased phosphorylation of Rad17 at Ser-635 (Figure 5a and Table 1), which is required for genotoxic stress response. ${ }^{36}$

IAP bind to caspases to hinder the progression of cell death. ${ }^{33}$ Three IAP (CIAP-1, XIAP and survivin) remained unaltered across the groups (Figure 5a and Table 1). However, ClAP-2 was found to be downregulated in all groups compared with air (Figure 5a and Table 1), suggesting that the cellular ability to attenuate apoptosis was diminished. For menthol and strawberry flavors, the decrease was significantly greater compared with non-flavored smoke (Table 1).

HSPs are constitutively expressed and act as molecular chaperones to modulate apoptosis in both positive and negative ways. ${ }^{37}$ We analyzed the expression of four HSPs in chronically smoke-exposed cultures, namely HSP27, HSP60, HSP70 and HO-1/ HMOX1/HSP32. Previous studies have demonstrated the association of HSPs with tobacco smoke-induced toxicity. ${ }^{38}$ Chronic nonflavored and flavored little cigar smoke exposure caused an increase in the four HSPs tested here, indicating an adaptive cellular response towards the stress induced by tobacco smoke. All the HSPs tested showed increased levels in chronic smokeexposed cultures irrespective of flavor, with marked increases in HSP60 and HO-1/HMOX1/HSP32 (Figure 5a and Table 1). Furthermore, peach flavor significantly increased HSP27 levels compared with non-flavored smoke (Figure $5 a$ and Table 1 ).

We further evaluated the levels of procaspase- 3 and cleaved caspase-3 in chronic smoke-exposed culture lysates to evaluate the extent of activation of apoptosis following smoke exposure. Both flavored and non-flavored little cigar smoke exposure increased pro- and cleaved caspase-3 levels, signifying apoptosis (Figure $5 \mathrm{a}$ and Table 1). Additionally, hypoxia inducible factor-1a (HIF-1a), a hypoxic transcriptional activator ${ }^{39}$ was elevated in all smoke-exposed cultures (Figure 5a and Table 1). However, claspin, a cell cycle check point protein and clusterin, an antiapoptotic heterodimeric glycoprotein and antiapoptotic enzyme HO-2/ HMOX2 levels remained identical across the exposure groups $^{40-42}$ (Figure 5a and Table 1).

Using the list of significantly altered and phosphorylated apoptotic proteins in chronic smoke-exposed cultures, we constructed protein-protein interaction networks using the STRING v.10 algorithm (Figure 5b). The network shows that execution of apoptosis by caspase- 3 in chronic smoke-exposed cultures is driven by both the intrinsic and the extrinsic pathways (Figure 5b). The intrinsic pathway was activated following decreased antiapoptotic $\mathrm{BCl}-2$ protein with increased proapoptotic Bad, leading to cytochrome $c$ release. TRAIL death receptors mediated the extrinsic apoptotic pathway in chronic smoked cultures (Figure 5b). Other associated proteins influenced the 
a

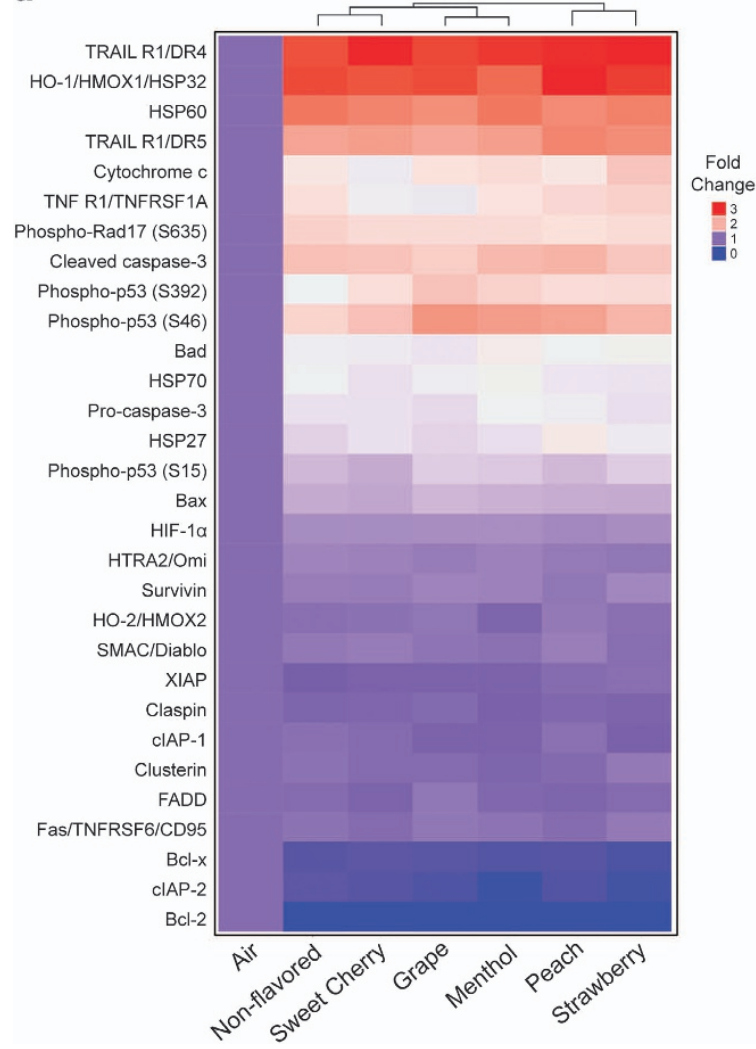

b

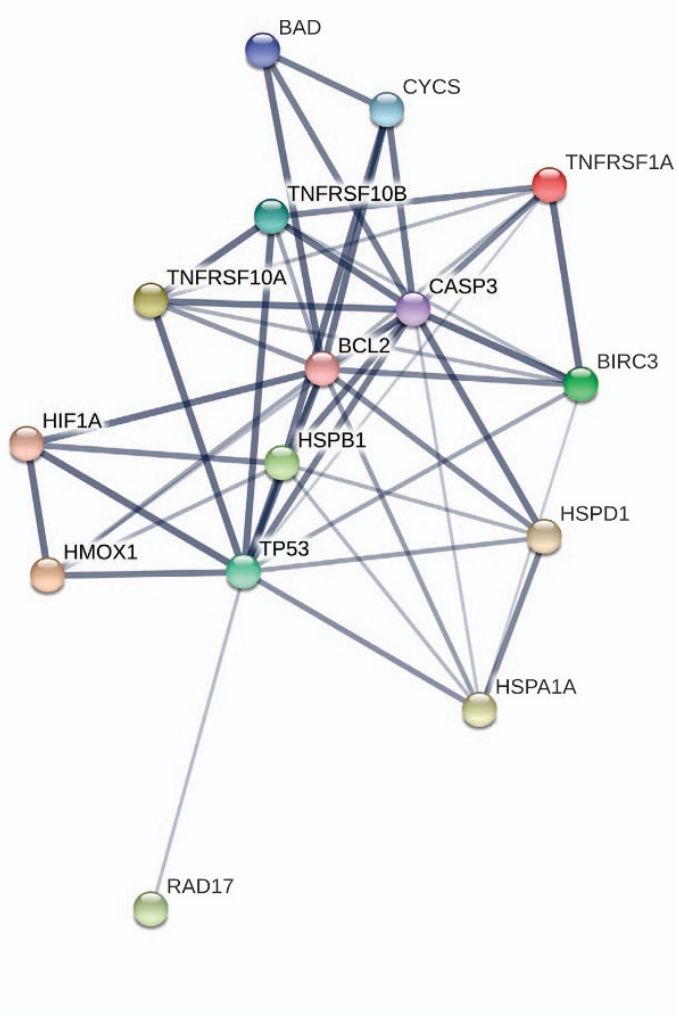

Figure 5. Chronic little cigar exposure induces changes in multiple apoptotic proteins. Polarized Calu-3 cells were chronically exposed to flavored and non-flavored little cigar smoke for 4 days and protein lysate was taken for apoptosis protein array analysis. (a) Heat map shows mean changes in expression of apoptotic proteins relative to air. Each value is the mean of four dot blots from two separate runs using lysate pooled from three cultures smoked in two separate experiments. (b) String network analysis showing relationship among 15 differentially expressed or phosphorylated apoptosis proteins by chronic little cigar exposure. Each node represents one differentially expressed or phosphorylated apoptotic protein. Line thickness between nodes represents extent of protein interaction.

apoptosis execution indirectly and the interactions between caspase- 3 and HSPs were not as strong as those seen with the $\mathrm{Bcl}-2$ family proteins and death receptors (Figure $5 \mathrm{~b}$ ).

\section{DISCUSSION}

In spite of the fact that in the United States of America the Master Settlement Agreement prohibits tobacco companies from targeting youths, ${ }^{43}$ tobacco manufacturers continue to use flavors like fruit, candy, liquor and coffee to recruit new smokers. ${ }^{44,45}$ Indeed, data from the National Youth Tobacco Survey (2011) suggest that more than $40 \%$ of middle and high school students in the Unites States of America have used flavored tobacco products. ${ }^{46}$ The effect of flavor compounds on health is a debatable topic. Although individual flavor constituents like anethole, eugenol, pulegone, estragole, piperonal, coumarin and myristicin exert toxic effects on biological systems in high doses, ${ }^{15-20}$ the biological activity of tobacco smoke is unaltered by these ingredients. ${ }^{47-49}$ Furthermore, researchers concluded that flavorants did not affect the relative amounts of 'Hoffmann analytes' and did not alter their genotoxicity or cytotoxicity. ${ }^{50,51}$ Similarly, flavored and non-flavored tobacco condensates had similar effects on tumor promotion in SENCAR mouse skin painting bioassays, although here no direct analysis of the mainstream smoke was performed. $^{52}$ Although flavors may not have additional toxic effects per se, it has previously been proposed that the addition of flavors to tobacco products is a crucial component in the initiation and sustenance of addiction, suggesting that their investigation is warranted. ${ }^{44,45,53}$

Our current study provides evidence that flavored little cigar smoke causes similar cytotoxicity to pulmonary epithelia as nonflavored little cigar smoke. For example, acute exposure to 10 puffs of little cigar smoke, altered live-dead cell staining, proapoptotic and apoptotic cell staining and autophagosome formation, irrespective of flavor (Figures 1 and 2). We also observed that some flavors were potentially more harmful than others. For example, the menthol, peach and strawberry flavors significantly increased cell death compared with non-flavored little cigars following acute smoke exposure (Figure 1b). Similarly, acute exposure to sweet cherry, menthol and peach flavors significantly increased the formation of proapoptotic cells compared with non-flavored little cigars (Figure 2a). The ability of tobacco smoke exposure to elicit an autophagic response was also evaluated, and we observed that autophagosome formation was enhanced for all flavors (Figure 2c). However chronically exposed air-liquid interface cultures showed uniformly increased LC3B-II protein levels, indicating an increase in autophagy (Figures $4 \mathrm{~b}$ and $\mathrm{c}$ ). As all tested flavors induced apoptosis, we then used protein array analysis to evaluate additional apoptotic proteins. We identified similar responses following exposure to smoke from both non-flavored and flavored little cigars, suggesting that all of the little cigars with or without flavor caused activation of both intrinsic and extrinsic pathways of apoptosis (Figures $5 a$ and b).

Cigarette smoke-exposed airway epithelia in vitro give similar responses as seen in vivo, including inhibition of the CFTR anion channel, increased mucin secretion and induction of 
Table 1. Fold change of 30 apoptotic proteins as determined by microarray in chronic little cigar smoke-exposed polarized Calu-3 cultures, with or without flavor

\begin{tabular}{|c|c|c|c|c|c|c|c|c|}
\hline Protein & Air & Non-flavored & Sweet Cherry & Grape & Menthol & Peach & Strawberry & P-value \\
\hline Bad & $1.00 \pm 0.01$ & $1.64 \pm 0.11$ & $1.63 \pm 0.06$ & $1.60 \pm 0.07$ & $1.69 \pm 0.07$ & $1.66 \pm 0.10$ & $1.67 \pm 0.20$ & ** \\
\hline Bax & $1.00 \pm 0.01$ & $1.32 \pm 0.15$ & $1.29 \pm 0.06$ & $1.38 \pm 0.07$ & $1.36 \pm 0.13$ & $1.33 \pm 0.14$ & $1.32 \pm 0.17$ & NS \\
\hline $\mathrm{BCl}-2$ & $1.00 \pm 0.03$ & $0.55 \pm 0.06$ & $0.59 \pm 0.07$ & $0.58 \pm 0.08$ & $0.59 \pm 0.06$ & $0.60 \pm 0.04$ & $0.59 \pm 0.08$ & $* *$ \\
\hline Bcl-x & $1.00 \pm 0.05$ & $0.72 \pm 0.09$ & $0.74 \pm 0.07$ & $0.73 \pm 0.08$ & $0.70 \pm 0.12$ & $0.71 \pm 0.12$ & $0.66 \pm 0.08$ & NS \\
\hline Procaspase-3 & $1.00 \pm 0.01$ & $1.59 \pm 0.03$ & $1.59 \pm 0.05$ & $1.55 \pm 0.07$ & $1.66 \pm 0.04$ & $1.64 \pm 0.07$ & $1.58 \pm 0.08$ & $* *$ \\
\hline Cleaved caspase-3 & $1.00 \pm 0.09$ & $1.92 \pm 0.23$ & $1.90 \pm 0.24$ & $1.84 \pm 0.25$ & $1.96 \pm 0.21$ & $1.99 \pm 0.21$ & $1.88 \pm 0.19$ & * \\
\hline CIAP-1 & $1.00 \pm 0.08$ & $1.01 \pm 0.05$ & $0.99 \pm 0.06$ & $0.93 \pm 0.05$ & $0.93 \pm 0.05$ & $1.02 \pm 0.09$ & $0.93 \pm 0.04$ & NS \\
\hline CIAP-2 & $1.00 \pm 0.05$ & $0.75 \pm 0.05$ & $0.71 \pm 0.02$ & $0.68 \pm 0.03$ & $0.61 \pm 0.03^{\mathrm{a}}$ & $0.69 \pm 0.05$ & $0.63 \pm 0.03^{\mathrm{a}}$ & $* *$ \\
\hline Claspin & $1.00 \pm 0.01$ & $0.96 \pm 0.06$ & $0.96 \pm 0.02$ & $0.99 \pm 0.06$ & $0.93 \pm 0.02$ & $0.97 \pm 0.09$ & $0.95 \pm 0.03$ & NS \\
\hline Clusterin & $1.00 \pm 0.01$ & $1.03 \pm 0.07$ & $0.99 \pm 0.11$ & $0.99 \pm 0.10$ & $0.96 \pm 0.11$ & $0.99 \pm 0.14$ & $1.07 \pm 0.07$ & NS \\
\hline Cytochrome $c$ & $1.00 \pm 0.05$ & $1.71 \pm 0.08$ & $1.63 \pm 0.07$ & $1.73 \pm 0.09$ & $1.76 \pm 0.16$ & $1.71 \pm 0.07$ & $1.88 \pm 0.15$ & ** \\
\hline TRAIL R1/DR4 & $1.00 \pm 0.02$ & $2.55 \pm 0.25$ & $2.74 \pm 0.28$ & $2.59 \pm 0.30$ & $2.66 \pm 0.14$ & $2.70 \pm 0.28$ & $2.98 \pm 0.52$ & $* *$ \\
\hline TRAIL R1/DR5 & $1.00 \pm 0.00$ & $2.08 \pm 0.19$ & $2.11 \pm 0.06$ & $2.05 \pm 0.08$ & $2.10 \pm 0.09$ & $2.26 \pm 0.14$ & $2.21 \pm 0.11$ & ** \\
\hline FADD & $1.00 \pm 0.00$ & $1.00 \pm 0.09$ & $0.95 \pm 0.02$ & $1.05 \pm 0.06$ & $0.98 \pm 0.08$ & $0.95 \pm 0.08$ & $0.99 \pm 0.09$ & NS \\
\hline Fas/TNFRSF6/CD95 & $1.00 \pm 0.00$ & $1.03 \pm 0.02$ & $0.99 \pm 0.04$ & $1.05 \pm 0.06$ & $1.03 \pm 0.05$ & $1.00 \pm 0.03$ & $1.06 \pm 0.08$ & NS \\
\hline HIF-1a & $1.00 \pm 0.01$ & $1.17 \pm 0.04$ & $1.17 \pm 0.05$ & $1.17 \pm 0.01$ & $1.17 \pm 0.03$ & $1.14 \pm 0.05$ & $1.17 \pm 0.02$ & $* *$ \\
\hline HO-1/HMOX1/HSP32 & $1.00 \pm 0.06$ & $2.58 \pm 0.16$ & $2.53 \pm 0.14$ & $2.58 \pm 0.13$ & $2.40 \pm 0.13$ & $2.73 \pm 0.08$ & $2.63 \pm 0.25$ & ${ }^{* *}$ \\
\hline HO-2/HMOX2 & $1.00 \pm 0.02$ & $1.01 \pm 0.07$ & $1.02 \pm 0.04$ & $1.05 \pm 0.05$ & $0.96 \pm 0.05$ & $1.07 \pm 0.05$ & $1.01 \pm 0.03$ & NS \\
\hline HSP27 & $1.00 \pm 0.02$ & $1.51 \pm 0.09$ & $1.59 \pm 0.06$ & $1.52 \pm 0.03$ & $1.58 \pm 0.09$ & $1.70 \pm 0.12^{\mathrm{a}}$ & $1.63 \pm 0.08$ & $* *$ \\
\hline HSP60 & $1.00 \pm 0.01$ & $2.34 \pm 0.11$ & $2.27 \pm 0.19$ & $2.20 \pm 0.05$ & $2.33 \pm 0.09$ & $2.23 \pm 0.10$ & $2.29 \pm 0.15$ & ** \\
\hline HSP70 & $1.00 \pm 0.02$ & $1.66 \pm 0.12$ & $1.59 \pm 0.08$ & $1.64 \pm 0.17$ & $1.67 \pm 0.12$ & $1.61 \pm 0.18$ & $1.60 \pm 0.17$ & $* *$ \\
\hline HTRA2/Omi & $1.00 \pm 0.02$ & $1.12 \pm 0.09$ & $1.11 \pm 0.08$ & $1.08 \pm 0.09$ & $1.10 \pm 0.09$ & $1.07 \pm 0.04$ & $1.05 \pm 0.02$ & NS \\
\hline P-p53 (S15) & $1.00 \pm 0.01$ & $1.39 \pm 0.14$ & $1.32 \pm 0.18$ & $1.49 \pm 0.17$ & $1.47 \pm 0.10$ & $1.39 \pm 0.11$ & $1.49 \pm 0.08$ & ** \\
\hline P-p53 ( & & & & & & & & ${ }^{*} \underset{* *}{\operatorname{versus~SC}}$ \\
\hline P-p53 (S392) & $\begin{array}{l}1.00 \pm 0.02 \\
1.00 \pm 0.01\end{array}$ & $\begin{array}{l}1.81 \pm 0.14 \\
1.65 \pm 0.16\end{array}$ & $\begin{array}{l}1.91 \pm 0.19 \\
1.75 \pm 0.17\end{array}$ & $1.90 \pm 0.20^{\mathrm{a}}$ & $1.81 \pm 0.16$ & $\begin{array}{l}2.08 \pm 0.27 \\
1.76 \pm 0.12\end{array}$ & $\begin{array}{l}1.98 \pm 0.20 \\
1.77 \pm 0.10\end{array}$ & $* *$ \\
\hline P-Rad17 (S635) & $1.00 \pm 0.02$ & $1.82 \pm 0.06$ & $1.77 \pm 0.06$ & $1.77 \pm 0.11$ & $1.77 \pm 0.07$ & $1.74 \pm 0.09$ & $1.76 \pm 0.06$ & $* *$ \\
\hline SMAC/Diablo & $1.00 \pm 0.01$ & $1.06 \pm 0.03$ & $1.07 \pm 0.03$ & $1.04 \pm 0.03$ & $1.02 \pm 0.03$ & $1.09 \pm 0.05$ & $1.00 \pm 0.03$ & NS \\
\hline Survivin & $1.00 \pm 0.02$ & $1.08 \pm 0.08$ & $1.08 \pm 0.10$ & $1.12 \pm 0.06$ & $1.11 \pm 0.02$ & $1.05 \pm 0.04$ & $1.13 \pm 0.05$ & NS \\
\hline TNF RI/TNFRSF1A & $1.00 \pm 0.03$ & $1.75 \pm 0.04$ & $1.65 \pm 0.14$ & $1.62 \pm 0.13$ & $1.73 \pm 0.08$ & $1.79 \pm 0.07$ & $1.82 \pm 0.12$ & $* *$ \\
\hline XIAP & $1.00 \pm 0.02$ & $0.91 \pm 0.04$ & $0.94 \pm 0.09$ & $0.94 \pm 0.08$ & $0.94 \pm 0.09$ & $1.00 \pm 0.13$ & $1.01 \pm 0.10$ & NS \\
\hline
\end{tabular}

Abbreviations: NS, nonsignificant; SC, Sweet Cherry flavor. $P$-value column represents comparison of each smoke exposure group compared with air: ${ }^{*} \leqslant 0.05$; ** $\leqslant 0.001 ;{ }^{a} P \leqslant 0.05$ for the particular flavor compared with non-flavored smoke.

apoptosis. ${ }^{9,14,54,55}$ Furthermore, the Calu-3 cell line is widely accepted as a reliable in vitro model system of airway epithelia that has been used to predict in vivo pharmacological and toxicological effects. ${ }^{56-58}$ Hence, our observations with both adherent and air-liquid interface (ALI) cultures of Calu-3 cells may be used to predict potential in vivo implications of flavored and non-flavored little cigar smoke on airway epithelia. Based on our observations, we conclude that little cigars are highly cytotoxic and can induce cell damage and apoptosis. Furthermore, the addition of flavor leaves the cytotoxic effects of the little cigars unaltered, suggesting that they are equally as harmful, despite the mitigating taste effects. In conclusion, considering the appealing effects of these products to new smokers and their potential for toxicity, we propose that flavored little cigars should be regulated in a similar manner as flavored cigarettes.

\section{MATERIALS AND METHODS}

Calu-3 cell culture

Calu-3 cells were obtained from the American Type Culture Collection (ATCC, VA, USA) and cultured using Minimum Essential Medium Alpha Medium with $10 \%$ fetal bovine serum, penicillin-streptomycin and $1 \mathrm{mM}$ sodium pyruvate. For acute exposure, 40000 cells were seeded per well in 96-well plates (Corning, Corning, NY, USA), incubated overnight at $37^{\circ} \mathrm{C} /$ $5 \% \mathrm{CO}_{2}$ and used when the cells were $70-80 \%$ confluent. For chronic exposure, $2 \times 10^{5}$ cells were seeded per $12 \mathrm{~mm}$ collagen-coated transwells culture insert (Corning) for 2 days, that is, until they become monolayers, after which time, the apical media was removed to provide an ALI. Cultures were used when they were 7-10 days old.

\section{Tobacco smoke exposure}

All tobacco smoke was generated using an LM1 smoke engine (Borgwaldt, Hamburg, Germany). For acute exposures, cells on 96-well plates were exposed to $10 \times 35 \mathrm{ml}$ puffs of the gas phase of mainstream smoke by placing a polyvinyl alcohol-bound glass fiber filter (Whatman, ISO 3308 compliant), at a frequency of 1 puff per min in a custom-made chamber as described. ${ }^{14}$ For intracellular $\mathrm{Ca}^{2+}$ measurements, 1 puff per $30 \mathrm{~s}$ was selected, to follow alterations in fluorescence immediately after smoke exposure. For chronic exposures, Calu-3 ALI cultures were exposed to $10 \times 35 \mathrm{ml}$ puffs of whole tobacco smoke per day at a rate of 1 puff per min of a whole little cigar per day for 4 days in a specially designed Perspex smoke chamber before being transferred back into the culture media. ${ }^{14,59}$ During the exposure, cultures were bathed serosally with sterile Ringer's solution (in mM: $120 \mathrm{NaCl}, 5.2 \mathrm{KCl}, 1.2 \mathrm{MgCl}_{2}, 1.2 \mathrm{CaCl}_{2} \cdot 2 \mathrm{H}_{2} \mathrm{O}, 12 \mathrm{NaHCO}_{3}$, 24 HEPES, 10 glucose, pH 7.4). Cultures were washed apically with PBS $1 \mathrm{~h}$ after the exposure and media were changed daily on all cultures. Control cells were exposed to puffs of filtered air.

\section{Statistical analysis}

All experiments were performed on multiple replicates on a minimum of three separate occasions. For each outcome, we fitted a linear, mixed model with a fixed effect for exposure type and a random effect to account for a possible batch effect within samples run on the same day. These models were used to construct statistical tests to determine whether the effect of air on an outcome was significantly different from the effect of each of the other exposures on that outcome. Similarly, we tested for differences in the effect of non-flavored Swisher Sweets compared with each of the flavored exposures on each outcome. In conducting these tests, a step-down approach was adopted to reduce inflation of the type 1 error. For any given outcome, we first performed an overall test based on its model to determine whether any association with exposure type 
existed, and follow-up tests for the individual exposure differences of interest were only performed if the overall test was found to be significant at the 0.05 level. $P$-values from the tests of exposure differences of interest were reported for outcomes with significant overall tests.

See Supplementary Methods for details of assays.

\section{ACKNOWLEDGEMENTS}

This work was funded by NIH/FDA Grant P50 HL120100-01. Research reported in this publication was supported by $\mathrm{NIH}$ and the Family Smoking Prevention and Tobacco Control Act. The content is solely the responsibility of the authors and does not necessarily represent the official views of the NIH or the Food and Drug Administration. We acknowledge the critical input of Drs Boris Reidel and Shernita Lee. We also thank Bryan Zorn for technical assistance.

\section{COMPETING INTEREST}

The authors declare no conflict of interest.

\section{REFERENCES}

1 Lim SS, Vos T, Flaxman AD, Danaei G, Shibuya K, Adair-Rohani $\mathrm{H}$ et al. A comparative risk assessment of burden of disease and injury attributable to 67 risk factors and risk factor clusters in 21 regions, 1990-2010: a systematic analysis for the Global Burden of Disease Study 2010. Lancet 2012; 380: 2224-2260.

2 Hu SS, Neff L, Agaku IT, Cox S, Day HR, Holder-Hayes E et al. Tobacco product use among adults-United States, 2013-2014. Morb Mortal Wkly Rep 2016; 65 685-691.

3 Jolly $\mathrm{DH}$. Exploring the use of little cigars by students at a historically black university. Prev Chronic Dis 2008; 5: A82.

4 Richter PA, Pederson LL, O'Hegarty MM. Young adult smoker risk perceptions of traditional cigarettes and nontraditional tobacco products. Am J Health Behav 2006; 30: 302-312.

5 USDHHS. Preventing tobacco use among youth and young adults: a report of the surgeon general. USDHHS, 2012.

6 Kostygina G, Glantz SA, Ling PM. Tobacco industry use of flavours to recruit new users of little cigars and cigarillos. Tob Control 2014; 25: 66-74.

7 Elmore S. Apoptosis: a review of programmed cell death. Toxicol Pathol 2007; 35: 495-516.

8 Orrenius S, Zhivotovsky B, Nicotera P. Regulation of cell death: the calciumapoptosis link. Nat Rev Mol Cell Biol 2003; 4: 552-565.

9 Rasmussen JE, Sheridan JT, Polk W, Davies CM, Tarran R. Cigarette smoke-induced $\mathrm{Ca}^{2+}$ release leads to cystic fibrosis transmembrane conductance regulator (CFTR) dysfunction. J Biol Chem 2014; 289: 7671-7681.

10 Hardingham GE, Chawla S, Johnson CM, Bading $\mathrm{H}$. Distinct functions of nuclear and cytoplasmic calcium in the control of gene expression. Nature 1997; 385: 260-265.

11 Hepler PK. The role of calcium in cell division. Cell Calcium 1994; 16: 322-330.

12 Monteith GR, McAndrew D, Faddy HM, Roberts-Thomson SJ. Calcium and cancer: targeting $\mathrm{Ca}^{2+}$ transport. Nat Rev Cancer 2007; 7: 519-530.

13 Cantin AM, Hanrahan JW, Bilodeau G, Ellis L, Dupuis A, Liao J et al. Cystic fibrosis transmembrane conductance regulator function is suppressed in cigarette smokers. Am J Respir Crit Care Med 2006; 173: 1139-1144.

14 Clunes LA, Davies CM, Coakley RD, Aleksandrov AA, Henderson AG, Zeman KL et al. Cigarette smoke exposure induces CFTR internalization and insolubility, leading to airway surface liquid dehydration. FASEB J 2012; 26: 533-545.

15 Bristol DW. NTP 3-month toxicity studies of estragole (CAS No. 140-67-0) administered by gavage to F344/N rats and B6C3F1 mice. Toxic Rep Ser 2011; 82: 1-111.

16 Lake BG. Coumarin metabolism, toxicity and carcinogenicity: relevance for human risk assessment. Food Chem Toxicol 1999; 37: 423-453.

17 LaVoie EJ, Adams JD, Reinhardt J, Rivenson A, Hoffmann D. Toxicity studies on clove cigarette smoke and constituents of clove: determination of the LD50 of eugenol by intratracheal instillation in rats and hamsters. Arch Toxicol 1986; 59: 78-81.

18 Lee BK, Kim JH, Jung JW, Choi JW, Han ES, Lee SH et al. Myristicin-induced neurotoxicity in human neuroblastoma SK-N-SH cells. Toxicol Lett 2005; 157: 49-56.

19 Thorup I, Wurtzen G, Carstensen J, Olsen P. Short term toxicity study in rats dosed with pulegone and menthol. Toxicol Lett 1983; 19: 207-210.

20 Truhaut R, Le Bourhis B, Attia M, Glomot R, Newman J, Caldwell J. Chronic toxicity/ carcinogenicity study of trans-anethole in rats. Food Chem Toxicol 1989; 27: 11-20.

21 Martin SJ, Reutelingsperger CP, McGahon AJ, Rader JA, van Schie RC, LaFace DM et al. Early redistribution of plasma membrane phosphatidylserine is a general feature of apoptosis regardless of the initiating stimulus: inhibition by overexpression of Bcl-2 and Abl. J Exp Med 1995; 182: 1545-1556.
22 Donnenberg VS, Donnenberg AD. Coping with artifact in the analysis of flow cytometric data. Methods 2015; 82: 3-11.

23 Berridge MJ, Lipp P, Bootman MD. The versatility and universality of calcium signalling. Nat Rev Mol Cell Biol 2000; 1: 11-21.

24 Liou J, Kim ML, Heo WD, Jones JT, Myers JW, Ferrell JE Jr et al. STIM is a $\mathrm{Ca}^{2+}$ sensor essential for $\mathrm{Ca}^{2+}$-store-depletion-triggered $\mathrm{Ca}^{2+}$ influx. Curr Biol 2005; 15: 1235-1241.

25 Kim HP, Wang X, Chen ZH, Lee SJ, Huang MH, Wang Y et al. Autophagic proteins regulate cigarette smoke-induced apoptosis: protective role of heme oxygenase1. Autophagy 2008; 4: 887-895.

26 Chen ZH, Kim HP, Sciurba FC, Lee SJ, Feghali-Bostwick C, Stolz DB et al. Egr-1 regulates autophagy in cigarette smoke-induced chronic obstructive pulmonary disease. PLoS One 2008; 3: e3316.

27 An $\mathrm{CH}$, Wang XM, Lam HC, Ifedigbo E, Washko GR, Ryter SW et al. TLR4 deficiency promotes autophagy during cigarette smoke-induced pulmonary emphysema. Am J Physiol Lung Cell Mol Physiol 2012; 303: L748-L757.

28 Demedts IK, Demoor T, Bracke KR, Joos GF, Brusselle GG. Role of apoptosis in the pathogenesis of COPD and pulmonary emphysema. Respir Res 2006; 7: 53.

29 Plataki M, Tzortzaki E, Rytila P, Demosthenes M, Koutsopoulos A, Siafakas NM. Apoptotic mechanisms in the pathogenesis of COPD. Int J Chron Obstruct Pulmon Dis 2006; 1: 161-171.

30 Budihardjo I, Oliver H, Lutter M, Luo X, Wang X. Biochemical pathways of caspase activation during apoptosis. Annu Rev Cell Dev Biol 1999; 15: 269-290.

31 Fridman JS, Lowe SW. Control of apoptosis by p53. Oncogene 2003; 22: 9030-9040.

32 Lanneau D, Brunet M, Frisan E, Solary E, Fontenay M, Garrido C. Heat shock proteins: essential proteins for apoptosis regulation. J Cell Mol Med 2008; 12 743-761.

33 Deveraux QL, Reed JC. IAP family proteins - suppressors of apoptosis. Genes Dev 1999; 13: 239-252.

34 Cai J, Yang J, Jones DP. Mitochondrial control of apoptosis: the role of cytochrome c. Biochim Biophys Acta 1998; 1366: 139-149.

35 Banin S, Moyal L, Shieh S, Taya Y, Anderson CW, Chessa L et al. Enhanced phosphorylation of p53 by ATM in response to DNA damage. Science 1998; 281: 1674-1677.

36 Bao S, Tibbetts RS, Brumbaugh KM, Fang Y, Richardson DA, Ali A et al. ATR/ATMmediated phosphorylation of human Rad17 is required for genotoxic stress responses. Nature 2001; 411: 969-974.

37 Feder ME, Hofmann GE. Heat-shock proteins, molecular chaperones, and the stress response: evolutionary and ecological physiology. Annu Rev Physiol 1999; 61: 243-282.

38 Hacker S, Lambers C, Hoetzenecker K, Pollreisz A, Aigner C, Lichtenauer M et al. Elevated HSP27, HSP70 and HSP90 alpha in chronic obstructive pulmonary disease: markers for immune activation and tissue destruction. Clin Lab 2009; 55 $31-40$.

39 Lee JW, Bae SH, Jeong JW, Kim SH, Kim KW. Hypoxia-inducible factor (HIF-1)alpha: its protein stability and biological functions. Exp Mol Med 2004; 36: 1-12.

40 Basuroy S, Bhattacharya S, Tcheranova D, Qu Y, Regan RF, Leffler CW et al. HO-2 provides endogenous protection against oxidative stress and apoptosis caused by TNF-alpha in cerebral vascular endothelial cells. Am J Physiol Cell Physiol 2006; 291: C897-C908.

41 Chini CC, Chen J. Human claspin is required for replication checkpoint control. J Biol Chem 2003; 278: 30057-30062.

42 Zhang H, Kim JK, Edwards CA, Xu Z, Taichman R, Wang CY. Clusterin inhibits apoptosis by interacting with activated Bax. Nat Cell Biol 2005; 7: 909-915.

43 Dachille K (ed). Pick Your Poison: Responses to the Marketing and Sale of Flavored Tobacco Products. Tobacco Control Legal Consortium: St Paul, MN, USA, 2009.

44 Carpenter CM, Wayne GF, Pauly JL, Koh HK, Connolly GN. New cigarette brands with flavors that appeal to youth: tobacco marketing strategies. Health Aff (Millwood) 2005; 24: 1601-1610.

45 Manning KC, Kelly KJ, Comello ML. Flavoured cigarettes, sensation seeking and adolescents' perceptions of cigarette brands. Tob Control 2009; 18: 459-465.

46 King BA, Tynan MA, Dube SR, Arrazola R. Flavored-little-cigar and flavoredcigarette use among U.S. middle and high school students. J Adolesc Health 2013; 54: 40-46.

47 Coggins CR, Sena EJ, Oldham MJ. A comprehensive evaluation of the toxicology of cigarette ingredients: inorganic compounds. Inhal Toxicol 2011; 23(Suppl 1): 157-171.

48 Gaworski CL, Oldham MJ, Wagner KA, Coggins CR, Patskan GJ. An evaluation of the toxicity of 95 ingredients added individually to experimental cigarettes: approach and methods. Inhal Toxicol 2011; 23(Suppl 1): 1-12.

49 Renne RA, Yoshimura H, Yoshino K, Lulham G, Minamisawa S, Tribukait A et al. Effects of flavoring and casing ingredients on the toxicity of mainstream cigarette smoke in rats. Inhal Toxicol 2006; 18: 685-706. 
50 Baker RR, Massey ED, Smith G. An overview of the effects of tobacco ingredients on smoke chemistry and toxicity. Food Chem Toxicol 2004; 42(Suppl): S53-S83.

51 Baker RR, Pereira da Silva JR, Smith G. The effect of tobacco ingredients on smoke chemistry. Part I: flavourings and additives. Food Chem Toxicol 2004; 42(Suppl): S3-37.

52 Gaworski CL, Heck JD, Bennett MB, Wenk ML. Toxicologic evaluation of flavor ingredients added to cigarette tobacco: skin painting bioassay of cigarette smoke condensate in SENCAR mice. Toxicology 1999; 139: 1-17.

53 Klein SM, Giovino GA, Barker DC, Tworek C, Cummings KM, O'Connor RJ. Use of flavored cigarettes among older adolescent and adult smokers: United States, 2004-2005. Nicotine Tob Res 2008; 10: 1209-1214.

54 Kode A, Yang SR, Rahman I. Differential effects of cigarette smoke on oxidative stress and proinflammatory cytokine release in primary human airway epithelial cells and in a variety of transformed alveolar epithelial cells. Respir Res 2006; 7: 132.

55 Kreindler JL, Jackson AD, Kemp PA, Bridges RJ, Danahay H. Inhibition of chloride secretion in human bronchial epithelial cells by cigarette smoke extract. Am J Physiol Lung Cell Mol Physiol 2005; 288: L894-L902.

56 Ihekwereme C, Esimone C, Shao D, Agu RU. Preliminary studies on validation of calu-3 cell line as a model for screening respiratory mucosa irritation and toxicity. Pharmaceutics 2014; 6: 268-280.
57 Ong HX, Traini D, Young PM. Pharmaceutical applications of the Calu-3 lung epithelia cell line. Expert Opin Drug Deliv 2013; 10: 1287-1302.

58 Stewart CE, Torr EE, Mohd Jamili NH, Bosquillon C, Sayers I. Evaluation of differentiated human bronchial epithelial cell culture systems for asthma research. J Allergy (Cairo) 2012; 2012: 943982.

59 Clunes LA, Bridges A, Alexis N, Tarran R. In vivo versus in vitro airway surface liquid nicotine levels following cigarette smoke exposure. J Anal Toxicol 2008; 32: 201-207.

\section{(c) (i)}

This work is licensed under a Creative Commons Attribution 4.0 International License. The images or other third party material in this article are included in the article's Creative Commons license, unless indicated otherwise in the credit line; if the material is not included under the Creative Commons license, users will need to obtain permission from the license holder to reproduce the material. To view a copy of this license, visit http://creativecommons.org/licenses/ by/4.0/

(c) The Author(s) 2017

Supplementary Information accompanies the paper on the Cell Death and Discovery website (http://www.nature.com/cddiscovery) 